\title{
Epizootiological Significance of Avian Clinical Cases Treated at the Poultry Unit of the University of Calabar Teaching and Research Farm, Calabar
}

\author{
P. U. Owai ${ }^{1}$, P. O. Ozung ${ }^{1} \&$ U. E. Ekpo ${ }^{1}$ \\ ${ }^{1}$ Animal Science Department, University of Calabar, Calabar, Nigeria \\ Correspondence: P. O. Ozung, Animal Science Department, University of Calabar, P. M. B. 1115, Calabar, \\ Nigeria. E-mail: iwatap3@yahoo.com; pascalozung@yahoo.com
}

\author{
Received: April 24, 2012 Accepted: May 14, 2012 Online Published: August 31, 2012 \\ doi:10.5539/jas.v4n10p232 URL: http://dx.doi.org/10.5539/jas.v4n10p232
}

\begin{abstract}
A study on Avian clinical cases handled at the Poultry Unit of the University of Calabar Teaching and Research Farm, Calabar from January 2006 - December 2009 revealed that a total of 120,344 cases were treated with an annual mean of 30,086 cases. A total of 20,881 cases or $17.35 \%$ were treated in the months of February followed by 14,400 cases or $11.97 \%$ in August months; 12,460 cases or $10.47 \%$ in July months, 11,107 or $9.23 \%$ in March months; 9,600 or $7.98 \%$ in September months; 9,300 or $7.80 \%$ in January months; 8,860 or $7.40 \%$ in May months; 8,796 or $7.31 \%$ in June months; 8,700 or $7.23 \%$ in November months; 5,800 or $4.82 \%$ in April months and 2,860 or $2.38 \%$ in October months, 8700 cases or $7.23 \%$ in December months.Of the clinical cases treated, other cases (otherwise referred to or comprising cases of Avitaminosis and other Nutritional deficiencies) accounted for 30,687 or $25.50 \%$; followed by Coccidiosis 18,216 or $15.14 \%$; Ectoparasitism, 16,930 or $14.07 \%$; Infectious Coryza 14,733 or 12.24\%; Helminthiasis, 12,655 or 10.52\%; Chronic Respiratory Disease (CRD) 10,960 or $9.11 \%$; Salmonellosis, 8988 or $7.47 \%$ and Fowl cholera 7,175 or $5.96 \%$. The Epizootiological significance of this study lies principally on an assessment of the causative agents, the environment, close monitoring, prompt and accurate diagnosis of these clinical cases as well as maintaining and also recommending effective disease control measures.
\end{abstract}

Keywords: epizootiological significance, avian clinical cases, Unical, poultry unit

\section{Introduction}

The intensive system of poultry keeping which birds may be continuously confined indoors until they are disposed of is the system most suitable for profitable and commercial poultry production (Ayivor \& Hellins, 1980; Salsbury, 1971; Oluyemi \& Roberts, 2000; Gietema, 1992). A disease is said to occur when there is a departure from the normal health of an animal and may therefore be caused as much by neglect or by the effects of microorganisms (Bains, 1979; Geoffrey, $1979 \&$ 1979; Olomu, 2003; Bayer, 1985). When diseases occur in a flock, it is a serious event and one that often causes anxiety and apprehension to the poultry farmer (Obioha, 1992; Balogun \& Ogundipe, 1986; Dafwang \& Ogundipe, 1986). When commercial poultry are reared intensively, a large number of birds occupy a relatively small area, and the occurrence of a disease can spread within the whole flock causing a high level of mortality and high financial losses to the farmer (Jordan \& Pattison, 1999).

Gietema (1992) and Barkish (1989) believe that the incidence and the importance of the different poultry diseases vary with time and that in the course of time, the measures that were taken to control these diseases have rendered certain diseases less prominent while others have become more important. Various prevalence rates of some important poultry diseases have been reported, while diseases have caused considerable losses to the poultry industry in Nigeria very conservative estimates show that about $10-20 \%$ of the chicken produced in the country die each year and diseases are the most important cause of these losses (Bishu, 1979; North \& Bell, 1990; Gillespie, 1992). The economic losses due to disease can mean the difference between success and failure in the poultry industry. This study was therefore undertaken to investigate, highlight, document avian clinical cases treated at Unical Poultry Farm and also recommend appropriate measures for their effective control and management. It will also help to update our knowledge of epizootological studies with respect to poultry diseases. The various interventions employed in the effective management of the various disease conditions will provide ready tools for the management of similar poultry establishment since commercial poultry production in 
the South South geo-political zone of Nigeria is practiced widely and is of top priority.

\section{Materials and Methods}

\subsection{Location of the Study}

The poultry unit is part of the University of Calabar Teaching and Research farm located in Calabar South Local Government Area of Cross River State of Nigeria. Calabar is located on Latitude $4^{\circ} 58^{\prime}$ North and Longitude $8^{\circ}$ 17' East (CR-SEEDS, 2006) on equatorial high tropical rain forest zone characterized by warm wet humid conditions. A climate is within the semi-equatorial (monsoonal) type in which heavy down pours of rain are normal with an average of $3000 \mathrm{~mm}$ per anum with concentration between March and November (Teco-Kotzi, 1969).

\subsection{Data Collection and Analysis}

The primary data for the study were provided by the farm records which included case Books (Registers) which included record of all the disease conditions handled and treated in the farm for the 4 year period of January, 2006 - December, 2009. Post-mortem registers of cases carried out in the farm were also examined and scrutinized. Specimen of birds managed in the farm within this period included Harco Pullets and Layers, Harco Cockerels, Anak Broilers, Hubbard Broilers and Turkey poults and layers managed intensively in deep litter system with conventional feeds .

Specimen samples for laboratory examinations were sent to the reference laboratory at the Veterinary Headquarters located along Barracks Road, Calabar for proper analysis. In case of doubtful cases, specimen samples were also sent to the Nigerian Veterinary Research Reference Laboratory at Vom, Plateau State for more accurate diagnosis. The data of all cases treated were pooled together, collated, analyzed and presented using Descriptive Statistics in the form of Tables, Percentages, Means and Histogram. The total number of cases shown in each month (column) showed the total for that particular month for the 4 year period of study (e.g. the figures for January showed the total cases handled in the four (4) months of January within the period of study for four years and so for all the other months).

\section{Results}

The study revealed that a total of 120,344 cases were handled and treated in the Poultry Unit with an annual mean of 30,086 (Table 1). As a proportion of the total avian cases handled and treated, the monthly diagnosis (for the 4 years) and the total cases during the study period either increased progressively or fluctuated from month to month and peaked in the months of February with 20,881 cases (17.35\%) followed by 14,400 or $11.97 \%$ in August. However, as a proportion of the monthly (yearly) cases handled which showed a haphazard trend, the months of July recorded the next high value of 12,100 or $10.47 \%$ followed by 11.107 cases or $7.23 \%$ in March; 9.600 cases or $7.98 \%$ in September; 9380 cases or $7.80 \%$ in January; 7380 cases or $7.40 \%$ in May; 8796 cases or $7.31 \%$ in June; 8700 cases or $7.23 \%$ in December; 7500 cases or $6.24 \%$ in November; 5,800 cases of $4.82 \%$ in April while the least occurrence of 2,860 cases representing $2.38 \%$ were treated in the months of October (Table 1).

Table 1. Summary of Poultry Diseases treated at the Unical Poultry Unit (Jan. 2006 - Dec. 2009)

\begin{tabular}{|c|c|c|c|c|c|c|c|c|c|c|c|c|c|c|}
\hline Diseases & Jan. & Feb. & March & April & May & June & July & Aug. & Sept. & Oct. & Nov. & Dec. & Total & Prevalence $(\%)$ \\
\hline Infectious & 740 & 3000 & 745 & 1000 & 350 & 1028 & 2570 & 1800 & 2000 & - & - & 1500 & 14733 & 12.24 \\
\hline \multicolumn{15}{|l|}{ Coryza } \\
\hline CRD & - & - & 1000 & - & - & 740 & 2560 & 2400 & 2000 & 260 & 2000 & - & 10960 & 9.11 \\
\hline FC & 1000 & 1720 & 1745 & - & 710 & 2000 & - & - & - & - & - & - & 7175 & 5.96 \\
\hline Coccid. & 1720 & 3000 & 1936 & 1000 & 1980 & - & 2220 & 2600 & 2000 & 260 & - & 15000 & 18216 & 15.14 \\
\hline Helmint. & 1460 & 2800 & 1745 & - & 350 & 2000 & - & 2500 & - & 1800 & - & - & 12655 & 10.52 \\
\hline Ectopara. & - & 4000 & - & 3000 & - & - & 3150 & - & 2200 & 280 & 1800 & 2500 & 16930 & 14.07 \\
\hline Salmon. & - & 680 & 3000 & - & 320 & 1028 & - & 2500 & - & 260 & 1200 & - & 8988 & 7.47 \\
\hline Others & 4460 & 5681 & 936 & 800 & 5150 & 2000 & 1960 & 2600 & 1400 & - & 2500 & 3200 & 30687 & 25.50 \\
\hline Total & 9380 & 20881 & 11107 & 5800 & 8860 & 8796 & 12460 & 14400 & 9600 & 2860 & 7500 & 8700 & 120344 & 100.01 \\
\hline $\operatorname{Mean}(\mathrm{x})$ & 1173 & 2610 & 1388 & 725 & 1108 & 1000 & 1575 & 1800 & 1200 & 358 & 938 & 1088 & 15043 & \\
\hline$\%$ & 7.80 & 17.35 & 9.23 & 4.82 & 7.40 & 7.31 & 10.47 & 11.97 & 7.98 & 2.38 & 6.24 & 7.23 & 100.82 & \\
\hline
\end{tabular}

Source: From the study.

Key: CRD - Chronic Respiratory Disease; FC - Fowl Cholera; Coccid. - Coccidiosis; Helmint.- Helminthiasis; Ectopara.- Ectoparasitism; Salmon. - Salmonellosis.

In terms of clinical cases handled, diagnosed treated, (Figure 1) and reported as a proportion of the total cases 
diagnosed during the study period, Other Cases (otherwise referred to as Avitaminosis, Nutritional Deficiencies and Cannibalism) accounted for the highest figure of 30,687 or $25.50 \%$; followed by Coccidiosis 18,216 or 15.14\%; Ectoparasitism, 16,930 cases or 14.07\%; Infectious, Coryza 14,733 or 12.24\%; Helminthiasis, 12,655 or 10.52\%; Chronic Respiratory Disease (CRD) 10,960 or 9.11\%; Salmonellosis, 8,988 or 7.47\% and Fowl cholera 7,175 or $5.96 \%$, (Figure 1).

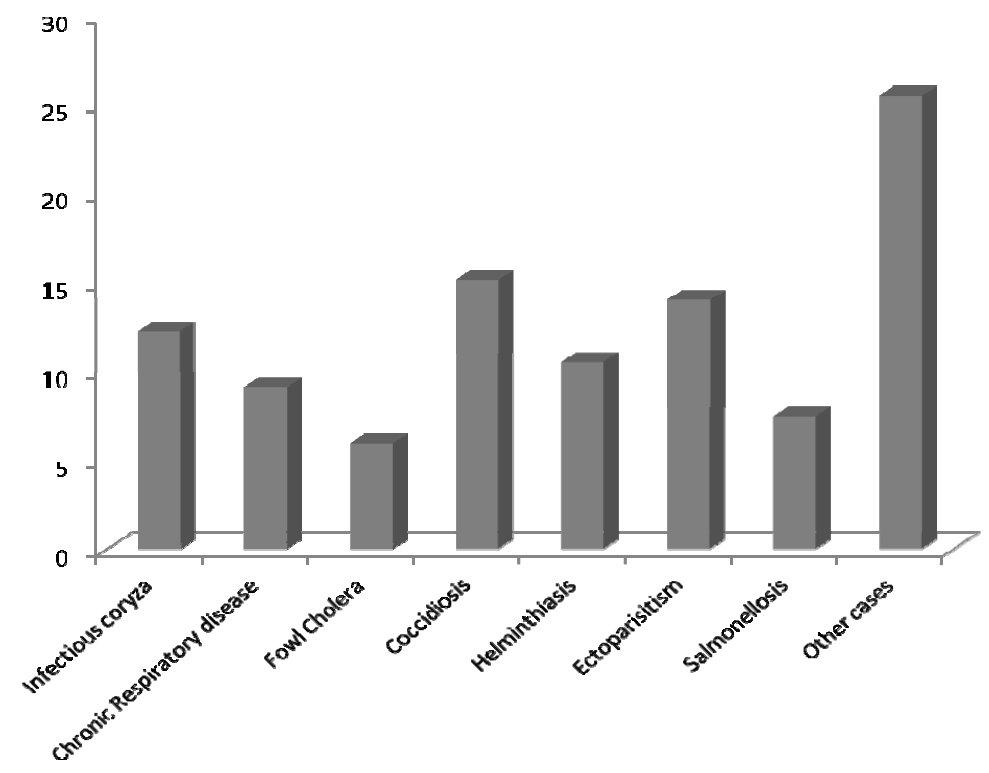

Figure 1. Histogram of Avian Clinical Diseases at UNICAL Poultry Farm (2006 - 2009)

\section{Discussion}

The study revealed that most of the Avian clinical cases handled, diagnosed and treated over the four year period were either on the increase or fluctuating and agreed with the observations of (Gietema, 1992; Halpin, 1978). The relatively high prevalence of other cases otherwise attributable to nutritional imbalances Mineralosis, Avitaminosis and Cannibalism not only indicate but clearly confirm the needs to meet these requirements in the poultry feeds since they are intensively managed. It is not surprising however because the feeds were composed in the farm and if adequate measures were taken to ensure enough balances, the scourge of these diseases would have been adequately reduced. However, the high rates agree with the observations of (North \& Bell, 1990). The high proportion of Coccidiosis is not surprising since the birds were managed intensively, in deep litter with very strong indications of poor litter management. The rates here are however higher than those reported in (Owai, 2008). The fluctuating annual increase in Coccidiosis for the period for the proportion of total diagnosis and total cases strongly indicate there must either have been an abrogated administration of Coccidiostatic or Coccidioccidal agents. The study also revealed remarkably high and increasing proportions of Infectious Coryza, Ectoparasitism, Helminthiasis and Chronic Respiratory Disease (CRD). The farm is located in a low and in a relatively damp environment, the enzootic appearances of these diseases therefore is not a surprise. Since the birds were intensively managed, the incidence of Helminthiasis would have been reduced to the barest minimum if there was a coordinated anthelminthic control programme. Notwithstanding however, the rates of all the three disease conditions are much higher than the findings in Owai, 2008. The study has also revealed that in spite of the therapeutic and improved management practices undertaken at the farm level, certain diseases such as Salmonellosis, Fowl cholera still continue to be recorded. The occurrences of these diseases were also in agreement with the observations of other researchers (Gietema, 1992; Bishu, 1979; Gillespie, 1992; Zaria, 1995).

The main determinants of these disease manifestations are evolving host susceptibility, periodicity in pathogen abundance and transmissibility and the ever changing environment that can support or repress a host of pathogens (Esuruoso et al., 2005). Interactions among those factors responsible for seasonal variations are into the intricate fabric of life. For many diseases, explanations for self-sustained oscillations still remain elusive. Urgent need for effective strategies to prevent and control the spread of emerging infections in the rapidly 
changing world however demands a deeper insight into the cyclic nature of diseases, (Jordan \& Pattison, 1999). The study revealed difference in disease peaks which reflect differences in their epizootiology (Esuruoso et al., 2005). Some disease conditions such as Coccidiosis, Chronic Respiratory Disease (CRD), Infectious Coryza are usually higher during the rainy season whereas Pox infections are generally higher during the dry harmattan period (Geoffrey, 1979; Gietema, 1992).

The study revealed the absence of Newcastle Disease (NCD), Infectious Bursal Disease (IBD) and Fowl Pox diseases. Since the birds were intensively managed, a well coordinated vaccination programme was in place hence the incidence of these diseases that are usually enzootic in our environment were reduced Balogun and Ogundipe, 1986). Sometimes, for the same infectious agents, infections recorded in two different forms may present a different pattern of incidence. Every disease occurs at any season of the year but some of them more frequently occurred and are of greater severity at certain times Esuruoso et al., 2005.

Close temporal clustering of seasonal peaks in diseases that share similar sources of exposure, suggests dominant routes of transmission, (Partz et al., 1996). Peaks in dissimilar disease conditions may sometimes occur under certain ambient temperature. Such synchronization in disease manifestation can be governed by environmental and social factors. In some instances periodicity of a given infection observed in a particular population may not be present in another (Loopes, 2006). Seasonal patterns can change over time, for example, after intense vaccinations the pattern of Fowl Pox, Newcastle and Gumboro may change, (North \& Bell, 1990) but explanations for these phenomena remain elusive and obscure as departure from a systematically observed pattern could reflect the evolution of a pathogen which may change or alter flock immunity (Chauhan \& Roy, 2007; Salsbury, 1971). If however birds are adequately fed and maintained, inoculated routinely and well protected from adverse environmental temperatures, the scourge of most of these diseases will be minimized, poultry will perform well and both meat and egg production will also improve.

\section{Conclusion}

From the results obtained from this study, it could be concluded that good management with regular vaccination exercise will help reduce the incidence of poultry diseases in well established farms.

\section{References}

Ajivor, V. K., \& Hellins, E. K. (1986). Poultry keeping in the tropics. University Press Limited. Ibadan.

Bains, S. B. C. (1979). Manual of Poultry Diseases, Hoffman la Roche and Co. Ltd, Switzerland. pp. 30-85.

Balogun, S. T., \& Ogundipe, S. O. (1986). Poultry Farmers Handbook of disease prevention and extension, Bulletin No. 28, Poultry Service No. 3 Augustine Press, Zaria. pp. 25-40.

Barkish, T. (1989). Poultry parasites and diseases, African farming and food, processing (Jan/Feb edition), Allan Charles Publishing Ltd. London.

Bayer, L. (1985). Book for Farmers Stock Diseases Harmony Projects Ltd. 78 Badagry Expressway, Lagos, pp. 96-100.

Bishu, C. (1979). Major diseases of economic Importance to poultry Industry in Nigeria and their control. In Olomu J. M. et al ed. Processing of the $1^{\text {st }}$.

Chauhan, H. V. S., \& Roy, S. (2007). Poultry diseases diagnosis and treatment, new age international publishers. New Delhi, India.

CR-SEEDS. (2005). Report of the Cross River State Economic Empowerment and development strategy, State planning Commission Calabar.

Dafwang, I. I., \& Ogundipe, S. O. (1987). Poultry Farmers Handbook of Disease Prevention, Extension Bulletin No. 28, Poultry Series No. 3, Agricultural Extension Research Liaison Services, Ahmadu Bello University, Zaria.

Esuruoso, G. O., Ijagbone, I. F., \& Olugasa, B. O. (2005). Introductory Epizootiology, Vet. Academic Resource Foundation (VABF) Vet. Academica Resource Publishers and consultants. University of Ibadan P. O. Box 14400. Ibadan, Oyo State.

Geoffrey, P. West. (1979). Black Veterinary Dictionary, English Language Book Society and Adam Charles Black, London, 13th edition. pp. 630-660.

Gietema, R. (1992). Chicken Farming (Background Information Management and instruction) Gbemi Sodepo Press Ltd. Nigeria. pp. 60-82. 
Gilleepie, J. R. (1999). Modern Livestock and Poultry Production (4th edition) Delmar Publishers Incorporated, USA. pp. 640-620.

Halpin, B. (1978). Pattern of Animal Diseases. The English Language Book Society. Balliere Tindall, Great Britain by J. W. Arrowsmith Bristol.

Jordan, F. T. W., \& Pattison, M. (1999). Poultry Diseases (4th Edition). W. B. Sanders, Harcourt Brace and Coy Ltd. University Press Cambridge, U. K. Ltd.

Lopes, D. S. (2006). ACB Spurious anto-correlation correlations with quarterly data further Monte Carlo results empire t-cons (pp. 320-350). In Journal of Public Health Policy, 27(1), 3-15.

North, N. O., \& Bell, D. D. (1990) Commercial Poultry Production Manual (4th edition) Chapman and Hall, London. pp. 800-820.

Obioha, F. C. (1992). A guide to Poultry Production in the tropics (pp 130-136). Accena Publishers Ltd. Nigeria.

Olomu, J. M. (2003). Poultry Production; A practical approach. A Jachem Publication. pp. 48-60.

Oluyemi, J. A., \& Roberts, F. A. (2000). Poultry Production in Warm West Climates, Spectrum Books Ltd. Ibadan. pp. 160-187.

Owai, P. U. (2008). Evaluation of Avian clinical cases treated at the Veterinary Clinic Calabar, Nigeria. Journal of Applied Sciences, Enugu, Nigeria, pp. 8076-8085.

Partz, J. A., Epstein, P. R., Buko, J. A., \& Balbuns, J. M. (1996). Global climate change and emerging infectious diseases, JAMA, 2(75), 217-230.

Salsbury, L. (1971). Salsbury's Manual of Poultry Diseases, pp. 5-48.

Teco-Kotzi. (1969). Survey and development plan for Calabar page 11 Consulting Engineers Nigeria Limited for the Government of South Eastern State of the Federal Republic of Nigeria, 41 Akim Road Calabar, Cross River State Nigeria.

Zaria, L. T. (1995). Incidence of ectoparasites of domestic fowl in an arid zone of Nigeria. Nigerian Journal of Animal production, 23(1\&2). 